\title{
Geographic distribution of Desmodus rotundus in Mexico under current and future climate change scenarios: Implications for bovine paralytic rabies infection
}

Heliot Zarza ${ }^{1,4 *}$

(iD) $0000-0003-2127-0811$

Enrique Martinez-Meyer ${ }^{2}$

(iD) 0000-0003-1184-9264

Gerardo Suzán 3

(iD) 0000-0003-2508-6376

Gerardo Ceballos ${ }^{1}$

(iD 0000-0001-8374-2656

${ }^{1}$ Instituto de Ecología, Universidad Nacional Autónoma de México, México, CDMX, 04510.

2Departamento de Zoología, Instituto de Biología,

Universidad Nacional Autónoma de México,

México, CDMX, 04510.

Current address: Centro del Cambio Global

y la Sustentabilidad en el Sureste, AC,

México, Villahermosa, 86080.

${ }^{3}$ Facultad de Medicina Veterinaria y Zootecnia, Universidad Nacional Autónoma de México, Ciudad Universitaria, México, CDMX, 04510.

${ }^{4}$ Present/permanent address: Departamento de Ciencias Ambientales, CBS, Universidad Autónoma

Metropolitana Unidad Lerma, Lerma de Villada,

Edo. de México, México, 52005.

*Corresponding author:

Tel: (728)282-2785 ext. 2100

Email address:

hzarza@iecologia.unam.mx

Received: 2016-06-26

Accepted: 2017-02-23

Published: 2017-06-30

Additional information and declarations can be found on page 13

(c) Copyright 2017 Heliot Zarza et al.

\begin{abstract}
Climate change may modify the spatial distribution of reservoirs hosting emerging and reemerging zoonotic pathogens, and forecasting these changes is essential for developing prevention and adaptation strategies. The most important reservoir of bovine paralytic rabies in tropical countries, is the vampire bat (Desmodus rotundus). In Mexico, the cattle industry loses more than $\$ 2.6$ million US dollar, annually to this infectious disease. Therefore, we predicted the change in the distribution of $D$. rotundus due to future climate change scenarios, and examined the likely effect that the change in its distribution will have on paralytic rabies infections in Mexico. We used the correlative maximum entropy based model algorithm to predict the potential distribution of $D$. rotundus. Consistent with the literature, our results showed that temperature was the variable most highly associated with the current distribution of vampire bats. The highest concentration of bovine rabies was in Central and Southeastern Mexico, regions that also have high cattle population densities. Furthermore, our climatic envelope models predicted that by $2050-2070, D$. rotundus will lose $20 \%$ of its current distribution while the northern and central regions of Mexico will become suitable habitats for $D$. rotundus. Together, our study provides an advanced notice of the likely change in spatial patterns of $D$. rotundus and bovine paralytic rabies, and presents an important tool for strengthening the National Epidemiological Surveillance System and Monitoring programmes, useful for establishing holistic, long-term strategies to control this disease in Mexico.
\end{abstract}

Keywords: vampire bat, rabies, maximum entropy model, livestock, climate change.

\section{Cite this as:}

Zarza H, Martínez-Meyer E, Suzán G, Ceballos G. Geographic distribution of Desmodus rotundus in Mexico under current and future climate change scenarios: Implications for bovine paralytic rabies infection. Veterinaria México OA. 2017;4(3). doi: 10.21753/ vmoa.4.3.390. 


\section{Introduction}

Rabies is a major viral zoonosis that affects mammals, including humans, and is globally distributed with a few notable exceptions. The rabies virus, transmitted in the saliva of sick animals by direct contact through deep bites or scratches, may be fatal once the infected individual develops clinical signs. ${ }^{1}$ Rabies is caused by the Rabies lyssavirus virus (RABV), one of the 11 identified virus species of the genus Lyssavirus (family Rhabdoviridae). It is widely distributed throughout the world, and is the only one reported in America. ${ }^{2}$ To date, nine antigenic variants of this genotype have been reported in Mexico., 3 Rabies is maintained in two epidemiological cycles, urban and sylvatic. In the urban rabies cycle, dogs are the main reservoir host, whereas wild mammals (i.e., carnivores and bats) are reservoirs of the sylvatic cycle. ${ }^{5}$

Globally, approximately 55000 people die annually from rabies, and most victims are children in underserved rural areas of Africa and Asia. ${ }^{6}$ In temperate environments, the primary reservoirs maintaining rabies are carnivores and insectivorous bats. ${ }^{7}$ However in tropical environments, the vampire bat (Desmodus rotundus) is the primary reservoir responsible for its transmission. ${ }^{4,8}$ In the last decade transmission of rabies by bats has become a significant public health threat in some parts of the world. 6,9,10 In Mexico, the transmission of rabies between carnivore species and bats does not appear to be a frequent occurrence, ${ }^{2}$ but this assessment may be biased towards vampire bats because of the economic impact to the livestock industry. ${ }^{11,12}$ Annual losses to rabies in the livestock industry are estimated at more than $\$ 23,000,000$.00 US dollars (NOM-067-ZOO-2007) ${ }^{11}$ and effective management requires epidemiological surveillance and weekly notifications to the National Epidemiological Surveillance System (SIVE) and the National Service of Agro- Alimentary Health, Safety and Quality (Senasica). In 2012, the national campaign against bovine paralytic rabies assisted 1112 bovine farms that reported bat attacks, with 360 confirmed rabies cases in cattle. ${ }^{13}$

The common vampire bat, a habitat generalist species with wide ecological plasticity that inhabits the tropical and subtropical regions in Mexico and south to central Chile and northern Argentina. ${ }^{14,15}$ In Mexico, D. rotundus has been recorded in 24 states, from central Sonora in the western part of the country eastward to the coastal plains of the Gulf of Mexico in northern Tamaulipas, and from the Pacific coast to the Yucatán Peninsula and Chiapas. ${ }^{12,13}$ It is commonly found in environments with warm temperatures (between 20 to $27^{\circ} \mathrm{C}$ ) and is best suited where there are little fluctuations ( 24 to $25^{\circ} \mathrm{C}$ ) in their roosts; $D$. rotundus can tolerate a temperature range from 35 to $37^{\circ} \mathrm{C} .16,17$ While the optimum range of relative humidity in their shelters is 70 to $100 \%$, it should not drop below $45 \%$ for survival. ${ }^{15}$

The geographic range of $D$. rotundus in Mexico does not extend outside the $10{ }^{\circ} \mathrm{C}$ minimum temperature isotherm or above an altitude of 2300 masl (meters above sea level.) ${ }^{14,16}$ Some studies suggest that if climatic conditions change, individuals are likely to relocate to new areas and roosts. ${ }^{18,19}$ Due to its ecological plasticity, the vampire bat can easily adapt to new landscapes modified by humans where loss of native plant cover, increased forage and greater abundance of domestic livestock have created suitable conditions for their breeding and feeding. ${ }^{4,8}$ In Mexico, it is expected that the combination of changes in land use and changes in global and regional climates will produce species distributional shifts, including reservoirs and vectors for infectious diseases, modifying the patterns of infectious 
disease occurrence. Thus, modelling species distribution in changing scenarios is becoming a major tool for conservation biology and for public health.

The ability to predict species distribution based on presence records may allow predicting the presence and absence of species in areas not previously sampled. ${ }^{20,21}$ If such predictions prove to be robust, it is possible to predict the response of species to the effects of global climate change. The ecological niche models (ENMs) have been used to predict the geographic range of species based on the relationship between environmental variables (e.g., biotic and abiotic variables) and the presence data of species. ${ }^{22}$ ENMs are founded on the classical concept of "niche" in ecology. ${ }^{23}$ This concept is based on two previous niche concepts; the first approach is based on environmental conditions such as temperature, precipitation, soil, etc., for which biological interactions such as competition are not relevant. ${ }^{24}$

This approach is widely used to understand coarse-scale ecological and geographic properties of species, ${ }^{21}$ instead the second approach considers that biological interactions such as competition, determine the geographic distribution of species. ${ }^{25}$

The latter approach is used to understand the fine-scale ecological and biological relationships between species. ${ }^{21}$

The objective of this study was to understand the current geographic distribution of $D$. rotundus under climate change scenarios in Mexico. We developed niche models to identify the current and future distribution patterns of $D$. rotundus, and compilated a database of bovine paralytic rabies cases to identify the areas of highest risk for bovine rabies, and to facilitate the development of preventive strategies in the country.

\section{Material and methods \\ Study area}

The study area comprises the entire territory of Mexico, between $14^{\circ} \mathrm{N}$ and $32^{\circ} \mathrm{N}$, $86^{\circ} \mathrm{W}$ and $118^{\circ} \mathrm{W}$. Mexico shares land borders with the US (to the north) and Guatemala and Belize (to the south). The total area of Mexico is approximately $1900000 \mathrm{~km}^{2}$ and is characterized by a great diversity of landscapes and climates. Approximately $85 \%$ of the country (except the Yucatán Peninsula and the coastal plains of the east and northwest) is formed by mountain ranges, plateaus and numerous valleys.

\section{Desmodus rotundus occurrence data}

To generate the present potential distribution map for $D$. rotundus, the study area was delimited using the known distribution of the species in Mexico.

We collected $D$. rotundus occurrence data from the National Mammal Collection of the Institute of Biology and the Museum of Natural History of the National University of Mexico (UNAM), the Mexican Commission for the Knowledge and Use of Biodiversity (Conabio), and the Global Biodiversity Information Facility. ${ }^{26}$ Data collected for each record included locality (geographic coordinates in decimal 
degrees), height above sea level and source of information. We used only records from 1980 to 2013, avoiding old and imprecise data.

\section{Bovine paralytic rabies and population data}

We used animal health weekly reports from the National Agro-Alimentary Health, Safety and Quality Service (Senasica), ${ }^{27}$ to develop a database of cases of bovine paralytic rabies from 2007 to 2015 . We also used information about the national pastoral range-livestock population from the Agricultural, Livestock and Forestry Census 2007.28 This data will be used to identify areas with more cattle and potential riesk areas. The information in both data sources was provided at the municipal level.

\section{Environmental data}

For this study, a total of 20 environmental variables were considered including 19 bioclimatic variables from temperature that reflect seasonal and annual trends of temperature and precipitation (Table 1). These variables were obtained from the WorldClim database ${ }^{29}$ for the 1950-2000 period. We used data for elevation above sea level, obtained from the Digital Elevation Model generated by the National Institute of Statistics, Geography and Informatics ${ }^{30}$; and used ArcGIS 10.231 to perform spatial analyses at a resolution of 30 arc-seconds $\left(\sim 1 \mathrm{~km}^{2}\right)$.

We used two Global Circulation Models (GCMs) to determine the likely distribution patterns of $D$. rotundus in Mexico for the decades of 2050 (average 20412060) and 2070 (average 2061-2080) at a spatial resolution of 30 seconds: Geophysical Fluid Dynamics Laboratory Model, version 3 (GFDL-CM3) and Hadley Centre Global Environment Model-ES version 2 (HadGEM2). ${ }^{29}$ These climate change predictive models were proposed in the Fifth Assessment Report of the Intergovernmental Panel on Climate Change (IPCC) and the Coupled Model Intercomparison Project, Phase 5. ${ }^{32}$ Both GCMs considered two greenhouse gas concentration trajectories or Representative Concentration Pathways (RCP); 4.5 and 8.5. The former assumes annual emissions will decline near the year 2050 and a conservative increase in population growth, while the latter assumes $\mathrm{CO}_{2}$ and methane emissions will continue to rise throughout the twenty-first century and a rapid increase in the human population. ${ }^{32}$

\section{Ecological niche model}

We used the correlative maximum entropy based model or MaxEnt program 33,34 to assess the potential distribution of $D$. rotundus in Mexico. MaxEnt is a robust algorithm that provides informative results and requires presence-only data. ${ }^{20,35-37}$ MaxEnt is a correlative model based on an adjustment Bayesian procedure under the principle of maximum entropy that is used to estimate probability distributions (i.e., more uniform distributions) based on records of the presence of a species. It is subject to restrictions given by the environmental information or other variables such as topography. ${ }^{33,34}$ To build the model, we divided the total number of records into two sets, a calibration data set (random selection of $75 \%$ of the data as training data) and a set of test data (25\%) in 100 replicates in 500 iterations 
Table 1. Contributions of environmental variables used in the model of Desmodus rotundus in Mexico.

\begin{tabular}{|c|c|}
\hline Variable & Percent contribution \\
\hline Temperature seasonality (Bio 4; SD × 100) & 49.5 \\
\hline Min temperature of coldest month (Bio $6{ }^{\circ}{ }^{\circ} \mathrm{C}$ ) & 16.6 \\
\hline Temperature annual range $\left(B i o ~ 7{ }^{\circ}{ }^{\circ} \mathrm{C}\right)$ & 10.0 \\
\hline Mean temperature of coldest quarter (Bio $11 ;{ }^{\circ} \mathrm{C}$ ) & 6.7 \\
\hline Isothermality (Bio 3) & 5.2 \\
\hline Elevation (m) & 2.8 \\
\hline Precipitation seasonality (Bio 15; mm) & 2.5 \\
\hline Annual precipitation (Bio 12; mm) & 2.0 \\
\hline Precipitation of wettest month (Bio 13; mm) & 1.4 \\
\hline Annual mean temperature (Bio $\left.1{ }^{\circ}{ }^{\circ} \mathrm{C}\right)$ & 1.0 \\
\hline Mean temperature of driest quarter (Bio $9 ;^{\circ} \mathrm{C}$ ) & 0.5 \\
\hline Max temperature of warmest month (Bio $5 ;{ }^{\circ} \mathrm{C}$ ) & 0.4 \\
\hline Mean diurnal range $\left(\mathrm{Bio} 2{ }^{\circ} \mathrm{C}\right)$ & 0.4 \\
\hline Precipitation of coldest quarter (Bio 19; mm) & 0.3 \\
\hline Mean temperature of wettest quarter (Bio $8 ;{ }^{\circ} \mathrm{C}$ ) & 0.2 \\
\hline Precipitation of driest month (Bio 14; mm) & 0.1 \\
\hline Mean temperature of warmest quarter $\left(\mathrm{Bio} 10 ;{ }^{\circ} \mathrm{C}\right.$ ) & 0.1 \\
\hline Precipitation of wettest quarter (Bio 16; mm) & 0.1 \\
\hline Precipitation of driest quarter (Bio 17; mm) & 0.1 \\
\hline Precipitation of warmest quarter (Bio 18; mm) & 0.1 \\
\hline
\end{tabular}

Note: Bold font indicates variables that contribute $\geq 1 \%$ to the model.

Source of data: WorldClim. ${ }^{29}$

with different random partitions (bootstrap method). To test the performance of the model and its discriminatory capacity, we used the $\mathrm{AUC}_{\text {test }}$ (area under the ROC curve based on the testing data), where values close to one show a good prediction and values close to 0.5 indicate that the model behaves randomly. ${ }^{33,38}$ It is import-

ant to note that although some studies have identified the limitations of the $A \cup C_{\text {test }}$ as a performance measure of models, 39,40 this test is often used as a single threshold-independent measure for model performance and is a highly effective measure of the performance of ordinal score models. ${ }^{36,41}$ The statistical significance of the model was evaluated using a binomial test which determines whethe the models are better than randomly obtained models. 33,38 Likewise, a Jackknife test was conducted to measure and determine which of these implemented variables were the most important for the presence of the species. ${ }^{33}$ Subsequently, we generated models of current and future distribution based on the probability threshold that minimizes the error of omission ( $\leq 10 \%$ training and validation) and the fraction of the predicted area to avoid overprediction. ${ }^{20,38,42}$ We used a multivariate environmental similarity surface (MESS) to assess the level of similarity of the environmental conditions of the predicted areas between the two GCMs employed. ${ }^{36}$ The results allowed us to distinguish areas of model extrapolation from those with similar environmental conditions at any site in the world. 
An additional component in developing niche models is the mobility area (M). This area is frequently much larger than the actual distribution of the species in question. ${ }^{43}$ Therefore, the predictions represent hypotheses about conditions that are similar to those where the species has been observed. These conditions are likely to be among the existing fundamental niche and the niche occupied by the species. ${ }^{20}$ Because Desmodus rotundus has a wide dispersal capacity and information about the natural history is available, we considered the entire country of Mexico as our M in the models. Currently the species is not present in the northern states of Mexico such as Baja California, Sonora, Chihuahua and Coahuila. ${ }^{13,15}$ However, these areas represent a potential opportunity to be colonized, if they present suitable environmental conditions in the future.

\section{Areas at risk of bovine paralytic rabies}

Predicted areas were identified as high risk due to probability estimates of the potential occurrence of $D$. rotundus in the study area. We superimposed maps of current and future $D$. rotundus distributions with database records of bovine paralytic rabies from Senasica ${ }^{27}$ to identify municipalities with potential risk of disease. We then input the layer of estimated number of free-ranging cattle from the Agricultural, Livestock and Forestry Census 2007,28 in each area to assess the potential extent of cattle susceptibility to the disease.

\section{Results and discussion}

\section{Bovine paralytic rabies distribution}

Bovine paralytic rabies remains a threat for livestock production in Latin America and Mexico where the vampire bat, Desmodus rotundus, is the main vector. ${ }^{4,11}$ From 2007 to 2015, 119389 cases of bovine paralytic rabies were reported, of which 1872 were confirmed, distributed in 477 municipalities in 25 Mexican states. States with the highest number of confirmed cases were Veracruz (342 confirmed cases, 25923 reports), San Luis Potosi (211 confirmed cases, 2624 reports), Yucatán (190 confirmed cases, 15783 reports), Tabasco (181 confirmed cases, 16132 reports), and Chiapas (127 confirmed cases, 13181 reports). States with the lowest number of reported cases were the State of Mexico, Guanajuato and Baja California Sur. Municipalities with the greatest number of positive cases of bovine paralytic rabies in the same period were: Tierra Blanca (75) and Papantla (61) in Veracruz, Huimanguillo in Tabasco, Mapastepec (60) in Chiapas, and Candelaria (60) in Campeche.

The annual number of confirmed cases fluctuated between 138 and 288, recorded three maxima: 288 cases in 2009, 275 in 2010 and, 243 in 2012 (Figure 1). When comparing seasons, we observed that most cases were reported during the dry season; a total of 1064 cases were reported between January and May, with two peaks in March and May (200 and 234 cases, respectively; Figure 2). Note that in this study we used correlative maxima entropy models to develop maps of the current distribution of suitable Desmodus rotundus habitats in Mexico. We then used climate change predictions to determine how changes in bioclimatic factors influence potential distribution of $D$. rotundus, the principal vector of rabies virus 


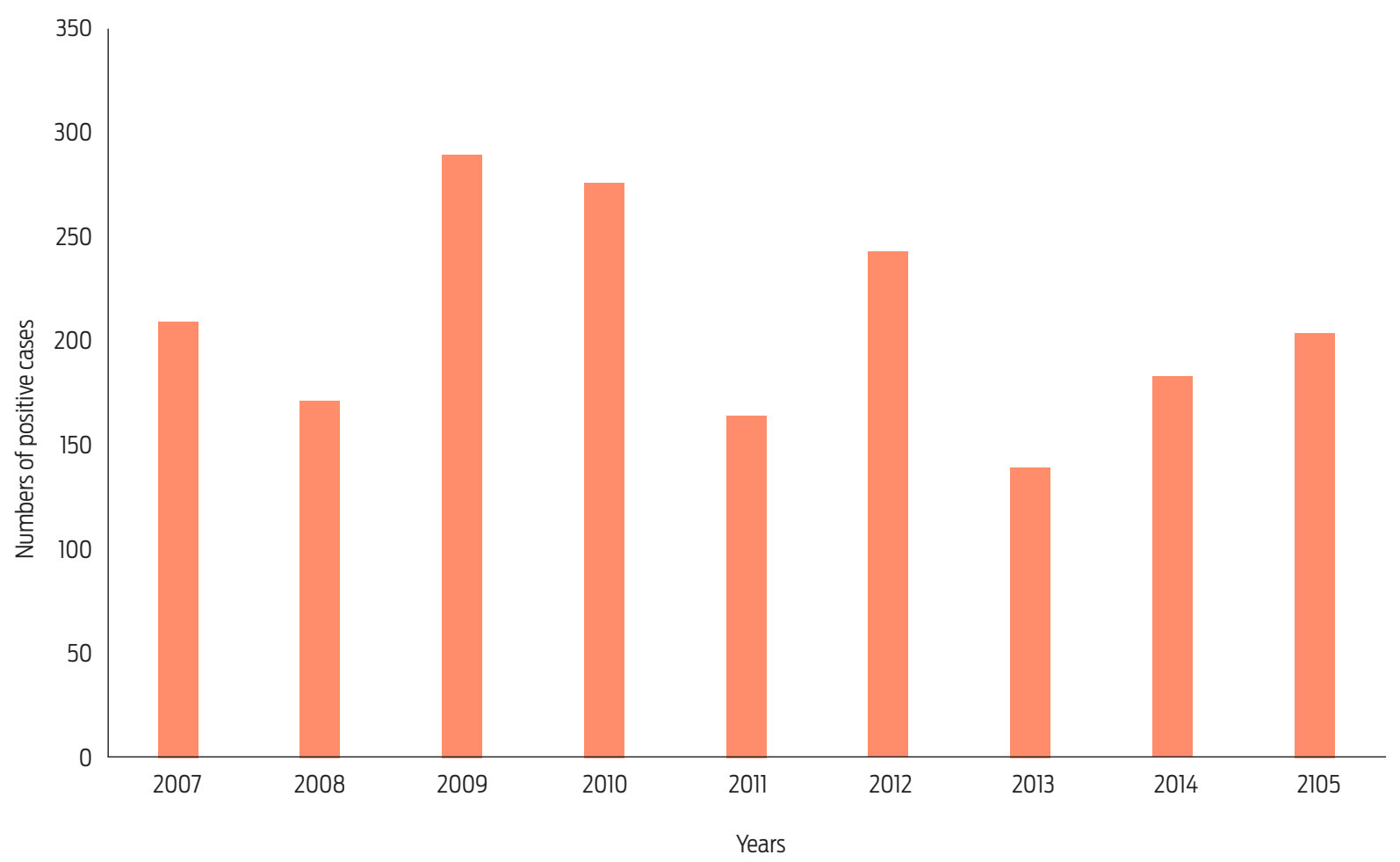

Figure 1. Annual number of cases of bovine paralytic rabies in Mexico, 2007-2015.

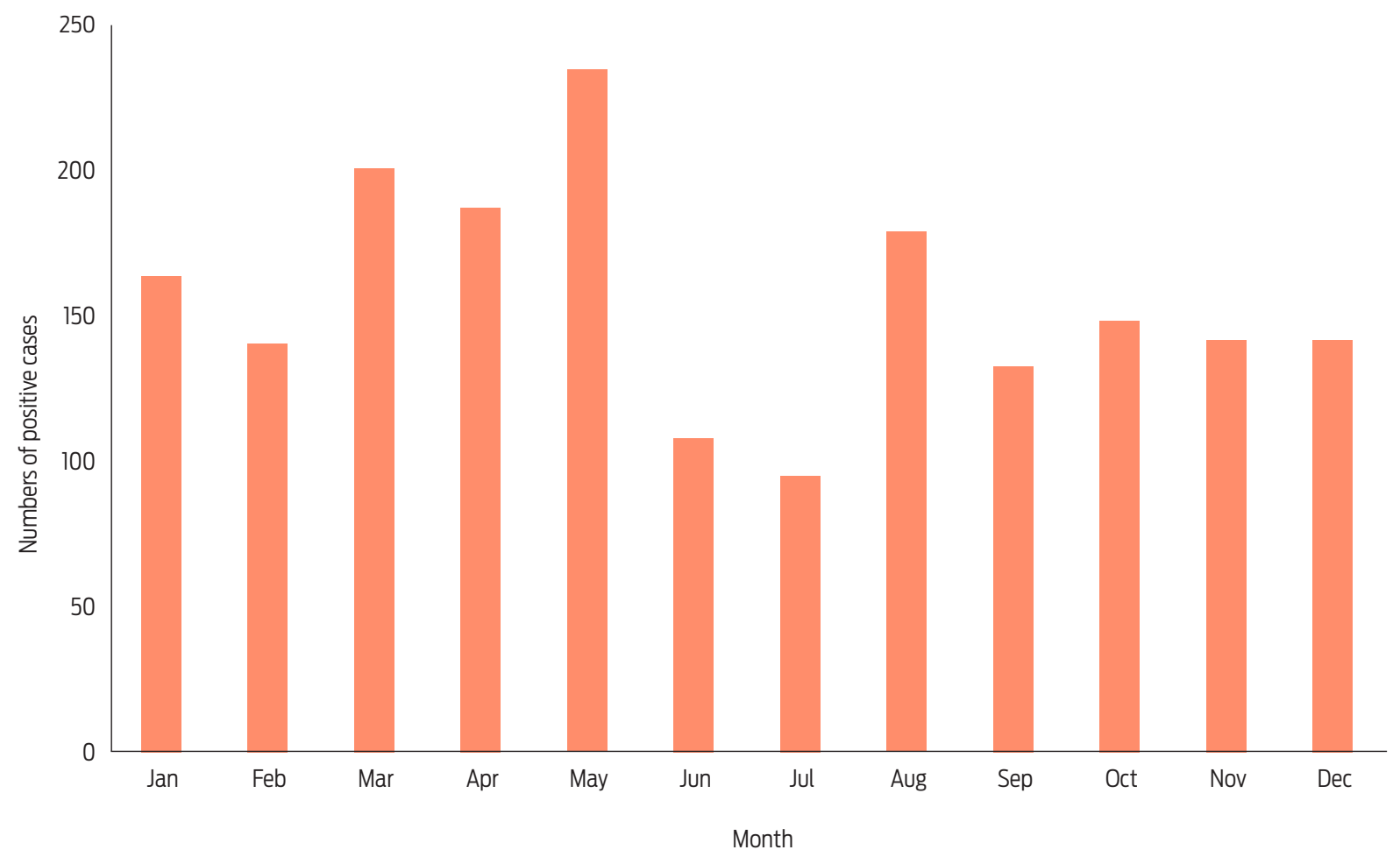

Figure 2. Number of monthly cases of bovine paralytic rabies in Mexico, 2007-2015. 
within pastoral range-livestock production systems, to identify potential bovine paralytic rabies risk areas. ${ }^{12}$

\section{Current distribution of Desmodus rotundus}

The current potential distribution of $D$. rotundus we generated from the 649 confirmed records for the period 1980-2013, performed well and had good adjustment $\left(A \cup C_{\text {test }}\right.$ value of $\left.0.95 \pm 0.029\right)$ and a low rate of omission $(P<0.0002)$. The most important variables associated with the presence of $D$. rotundus (table 1) were temperature seasonality ( $49.5 \%)$, followed by minimum temperature of coldest month (16.6 \%) and annual temperature range (10\%). The areas identified with a greater likelihood of the presence of $D$. rotundus maintain a temperature difference of less than $4{ }^{\circ} \mathrm{C}$ between the colder and warmer quarters, and both variables had low values, indicating low variation in temperature throughout the year.

Model prediction results for the current scenario indicate habitat suitability for Desmodus rotundus covers an area of $834965 \mathrm{~km}^{2}$ (Figure 3), and the areas with the most appropriate conditions (probability $>0.49$ ) are located along the coastal areas: The Pacific coast, from southern Sonora to the southwestern corner of the country, and the Gulf of Mexico coast, from central Tamaulipas to the Isthmus of Tehuantepec, Chiapas and the Yucatán Peninsula (Figure 3). Areas with a high probability of suitable conditions were primarily in the states of San Luis Potosi and Veracruz and in the southeastern region of the country. There were areas in the northern regions of the country, such as the states of Tamaulipas, Sonora and Sinaloa, in which $D$. rotundus are present in tropical and subtropical environments with warm temperatures that do not fluctuate more than $2{ }^{\circ} \mathrm{C}$ annually. However, the transformation of natural environments to grasslands for the development of the cattle industry, and the micro-climatic changes fostered by these disturbances have favoured the expansion of $D$. rotundus into other regions. ${ }^{12,15,44}$

\section{Future distribution of $\mathrm{D}$. rotundus}

Predicted risk maps for the 2050 and 2070 climate scenarios show a reduction in potential distribution of Desmodus rotundus as previously identified in the current scenario. The best predictive model of $D$. rotundus distribution under each of the two GCMs, GFDL-CM3 and HadGEM2, had AUC test values of $0.97 \pm 0.02$, indicating a high predictive power for both models. Under a conservative scenario of RCP 4.5, the distribution models under both GCMs show a marked reduction of total area compared to the current values: a reduction of $20 \%\left(170317 \mathrm{~km}^{2}\right)$ for the decade of 2050 and $28 \%$ (233 $\left.989 \mathrm{~km}^{2}\right)$ for the decade of 2070 (Figures 4, 5). A similar pattern was observed when the more development-intensive RCP 8.5 scenario was used: a reduction of $27 \%\left(229486 \mathrm{~km}^{2}\right)$ for the decade of 2050 and $34 \%\left(283471 \mathrm{~km}^{2}\right)$ for the decade of 2070 (Figures 4, 5). Comparison of the species distribution models revealed that with respect to the current geography, GFDL-CM3 GCM predicted reductions of $15 \%$ and $33 \%$ for both periods of time, whereas HadGEM2 predicted a reduction of $9 \%$ and $12 \%$ for 2050 and 2070, respectively.

The MESS analysis, which showed broad areas of similar environmental conditions under current and predicted future climatic conditions, also identified suitable 


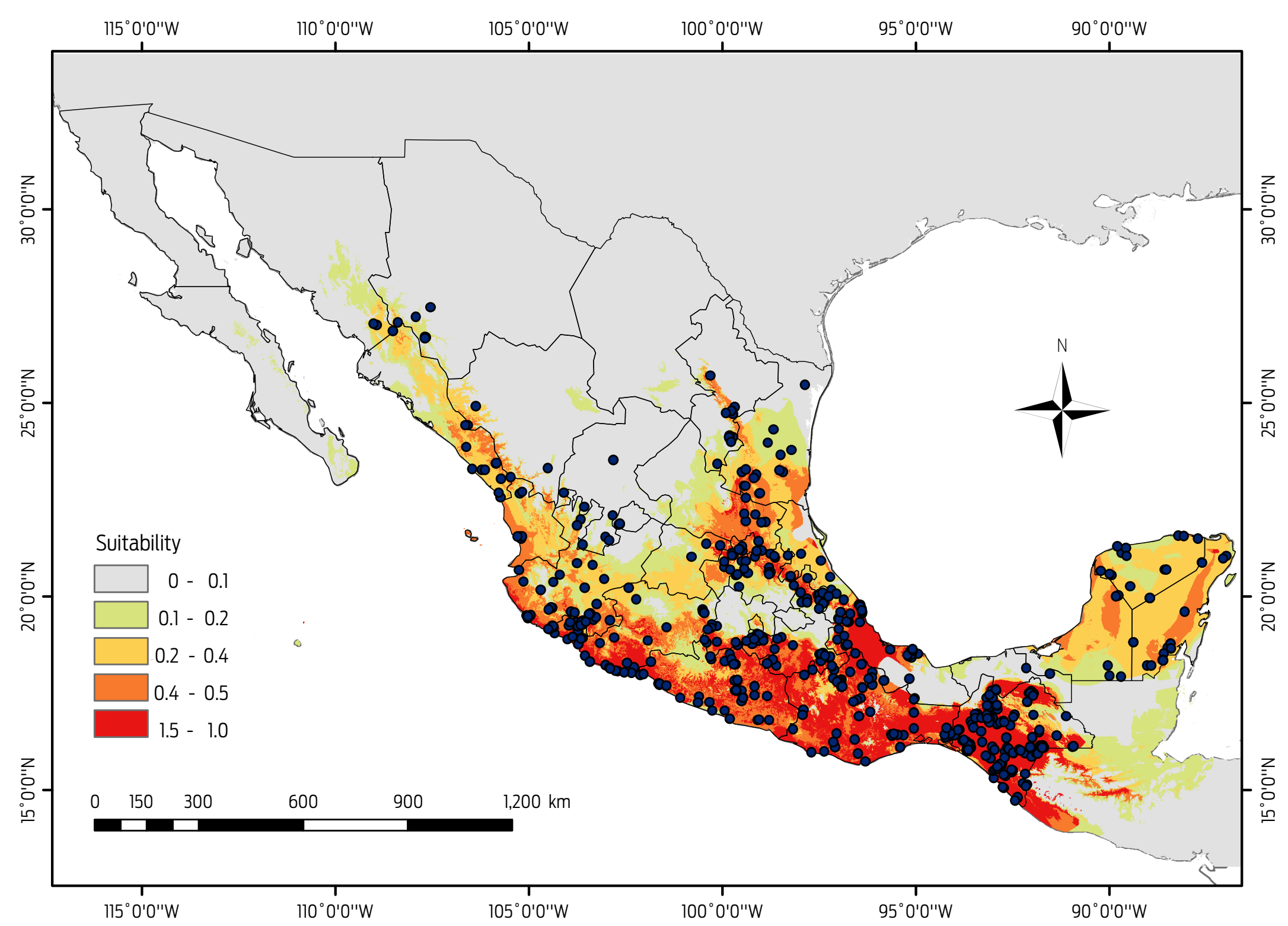

Figure 3. Current areas in Mexico identified as suitable for Desmodus rotundus using MaxEnt model. Blue points show localities of D. rotundus occurrence from 1980 to 2013. 
2050 RCP 4.5

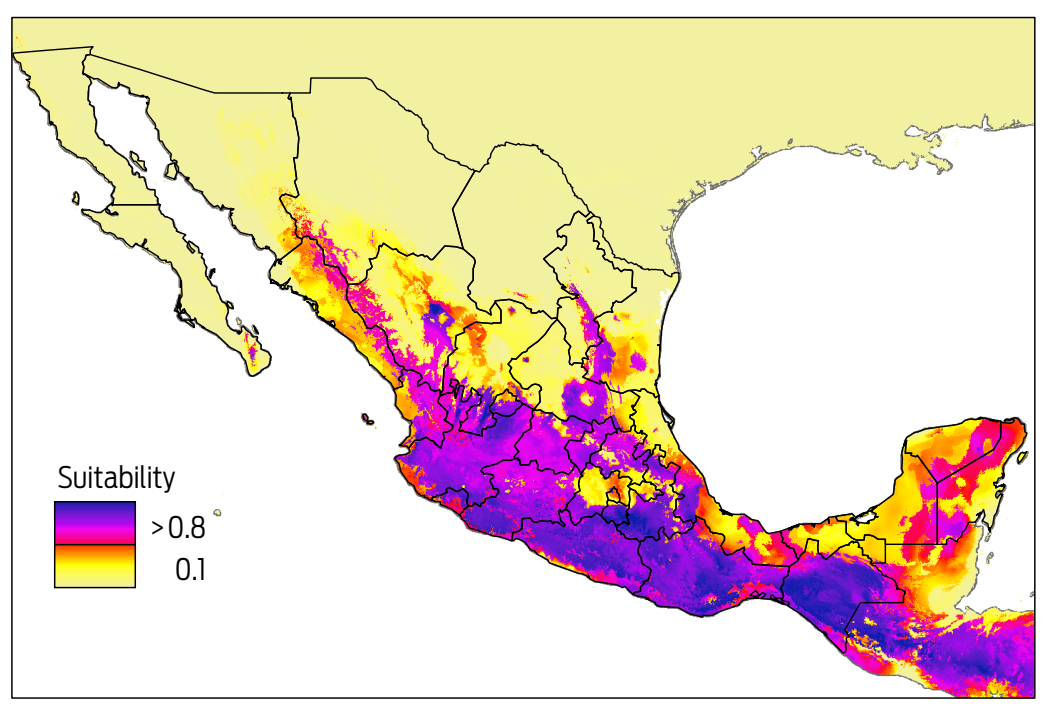

2070 RCP 4.5

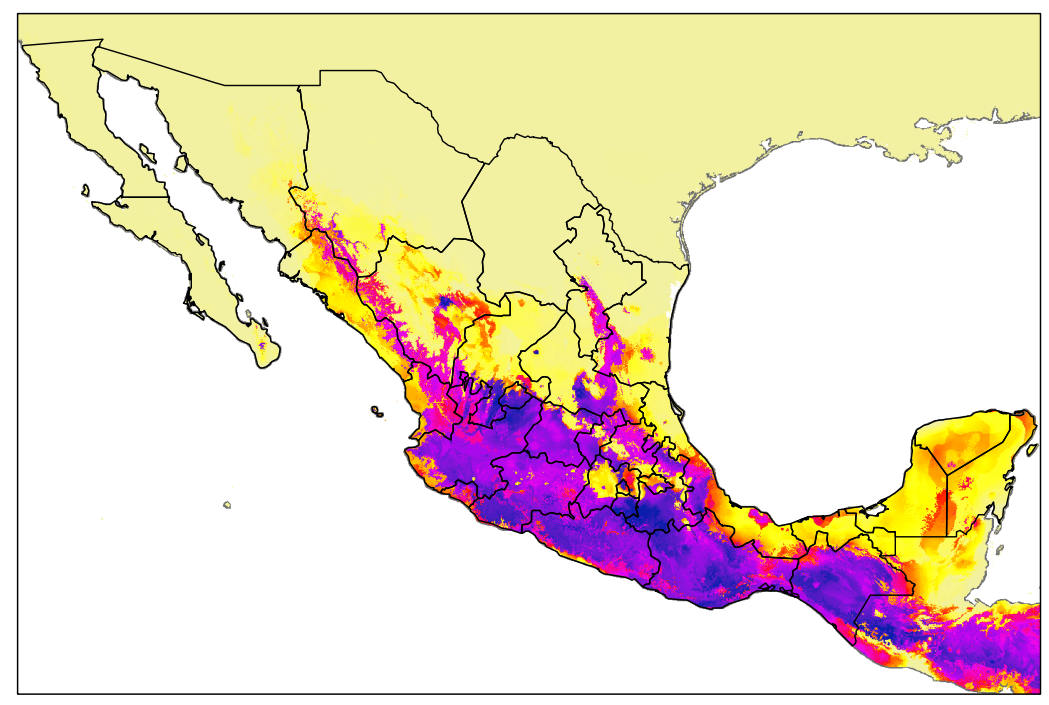

2050 RCP 8.5

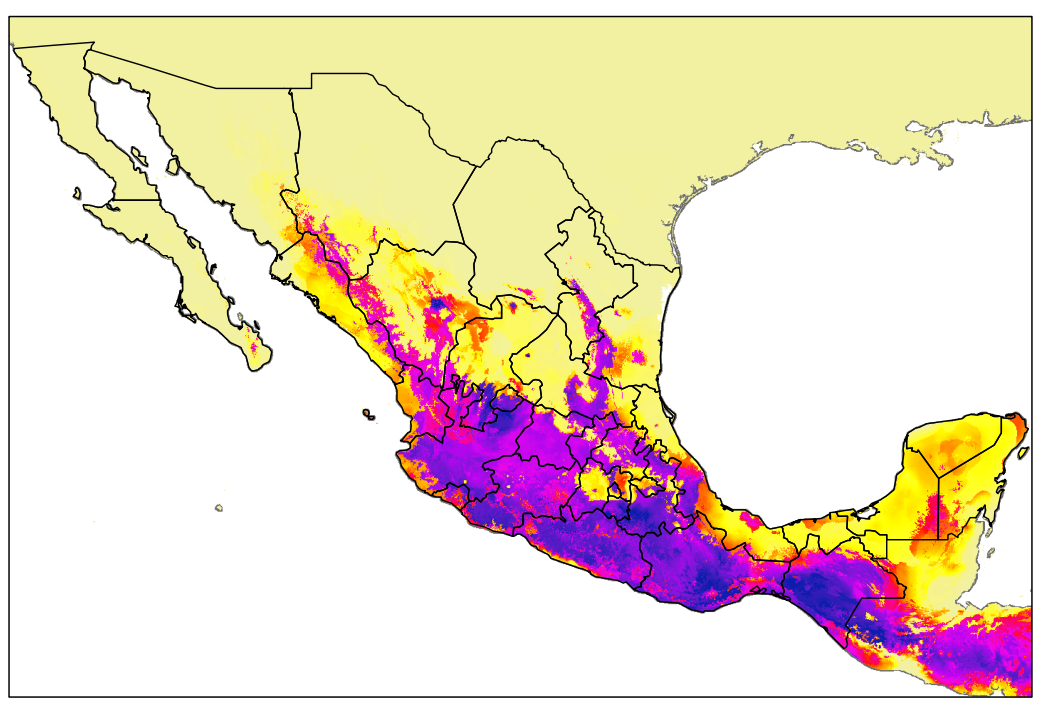

2070 RCP 8.5

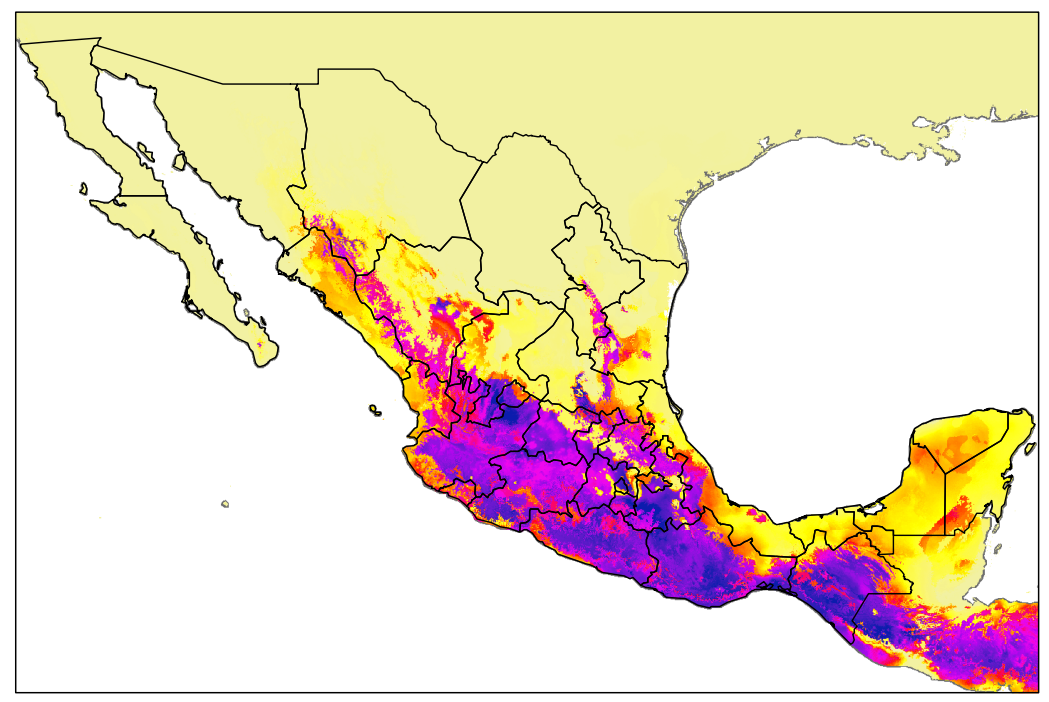

Figure 4. Modelled suitability for future distribution of Desmodus rotundus according to Global Climate Model GFDL-CM3 for two time periods (2050 and 2070), and two Representative Concentration Pathways (RCP 4.5 and 8.5). Left-hand column shows suitability values, with blue indicating more suitable conditions. 
2050 RCP 4.5

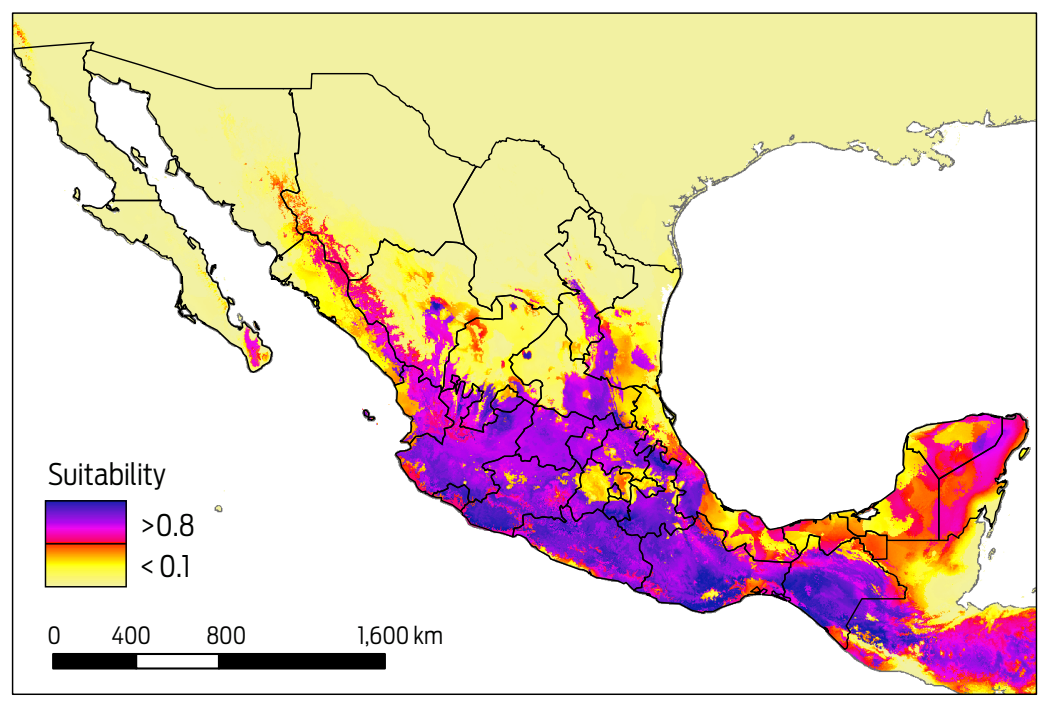

2070 RCP 4.5

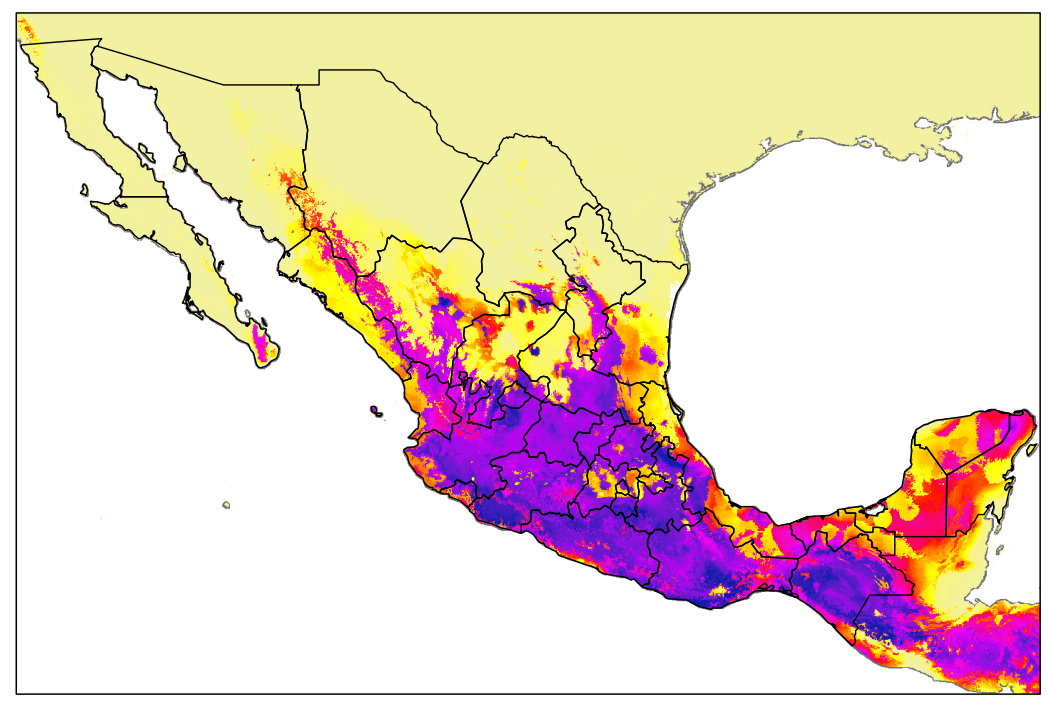

\section{RCP 8.5}

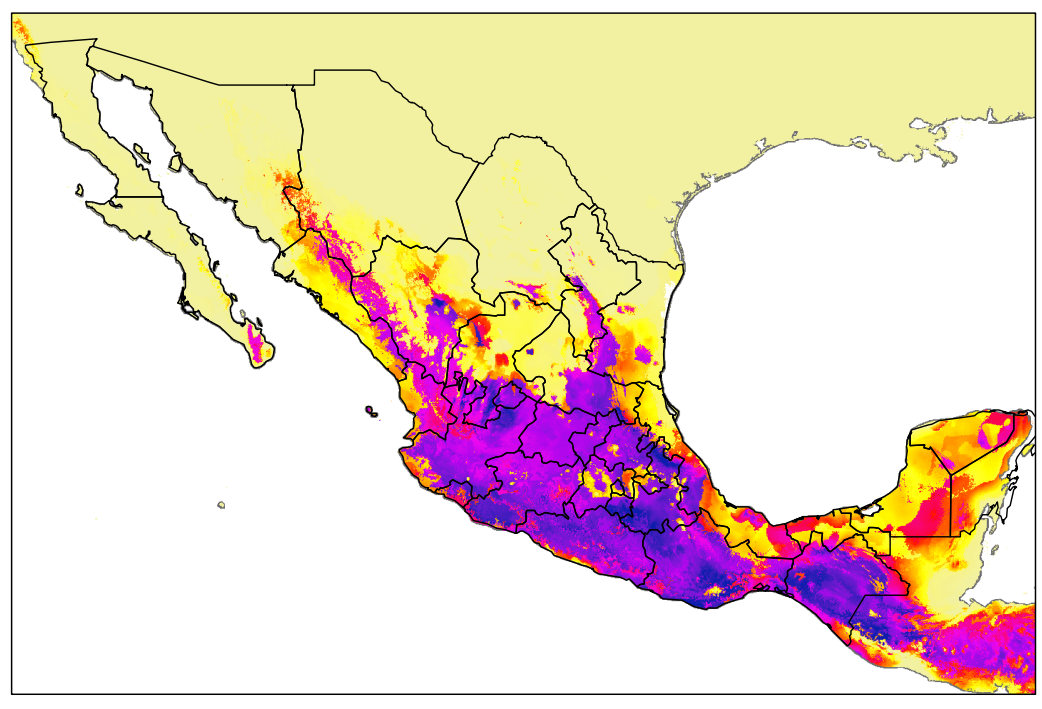

2070 RCP 8.5

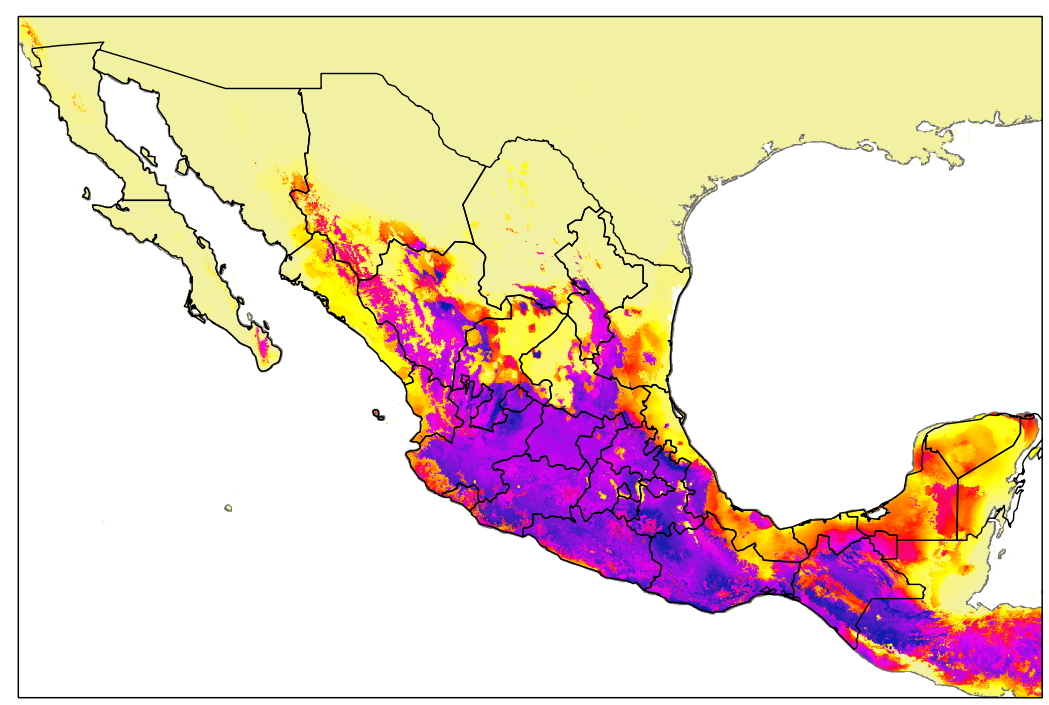

Figure 5. Modelled suitability for future distribution of Desmodus rotundus according to Global Climate Model HadGEM2 for two time periods (2050 and 2070), and two Representative Concentration Pathways (RCP 4.5 and 8.5). Left-hand column shows suitability values, with blue indicating more suitable conditions. 
areas where $D$. rotundus is currently absent, including central Mexico, Coahuila, Baja California, western Sonora, and northern Chihuahua. Under all IPCC climate change scenarios analyzed, $D$. rotundus expanded its range into the northwest of the country, occupying new areas in the states of Sonora, Sinaloa, Zacatecas, Aguascalientes, and Guanajuato, the northeast regions of Mexico in the states of Coahuila, Nuevo León and San Luis Potosi, and the Central Mexican Plateau, principally the states of Mexico, Puebla and Hidalgo.8,12 In contrast, the reduction in distribution occurred primarily in the southeastern portion of the country, notably in the Gulf Coastal Plain in southern Veracruz, Tabasco, southwestern Campeche, and the Yucatán Peninsula (Figures 4, 5).

It is important to note that while there may be some shift in the geographic patterns of the distribution of $D$. rotundus under future climate change scenarios, these changes are not significant on a nation-wide scale, and the species will continue to be located primarily in tropical and subtropical regions of the country. ${ }^{12,15}$ However, an increase in the suitable area for other vectors of the rabies disease and other biotic factors driving the dynamics of the disease, such as shelter and food availability and biological corridors, may contribute to an increased risk of the disease. $15,44,45$

Our results indicate significant changes in the pattern of distribution and incidence of bovine paralytic rabies in Mexico. The highest risk for bovine paralytic rabies occurs in the dry season (April and May). This pattern is consistent with reports of a spike in the number of rabies cases in Brazil, Colombia and Costa Rica during the dry season. ${ }^{46,47}$ We identified temperature as a principal determinant in the distribution of $D$. rotundus; it affects the spread of the rabies disease among tropical and semi-tropical environments and, the likelihood of its spread into more temperate areas that may experience increased temperature. We estimate that more than 600000 head of cattle in Mexico could be exposed to bovine paralytic rabies virus by 2050-2070, according to the current number of free-ranging cattle from the Agricultural, Livestock and Forestry Census 2007. ${ }^{28}$ Nevertheless, an increase of suitable areas for other vectors of the rabies disease and other biotic factors driving the dynamics of the disease, such as shelter and food availability and biological corridors, may contribute to the increased risk of the disease. ${ }^{8,44,48}$ This number is likely an underestimation because the cattle population is likely to exceed the values reported by the 2007 census that were used in the model and because of the ongoing and projected conversion of natural ecosystems to grazing land to accommodate livestock production.

\section{Conclusions}

Identification of current and future areas that are likely to support vectors of bovine paralytic rabies is a critical economic and social challenge that requires immediate attention. Bioclimatic conditions are a good predictor of the current distribution of one primary vector, Desmodus rotundus, and we used this relationship to show that by 2050-2070, $30 \%$ of the Mexican landscape will provide a suitable habitat for this species because of changing climatic regimes. This areal expansion will occur into northern and central Mexico where $D$. rotundus populations are currently minimal or absent. The increase in the area of cattle production and $D$. rotundus 
habitat overlap is a serious threat to the industry because of the likely increased incidence of bovine paralytic rabies. It is necessary to identify strategies, such as strengthening the National Epidemiological Surveillance System and monitoring programmes, to effectively maximize resources to address this challenge. These programmes will also benefit community health by reducing the probability of human rabies infections spread through vampire bat bites.

\section{Funding}

H. Zarza was supported during his Ph.D. studies by a fellowship (103123) from the Consejo Nacional de Ciencia y Tecnología (Mexico).

\section{Acknowledgements}

This paper constitutes a partial fulfilment towards Heliot Zarza's doctoral degree in the "Programa de Doctorado en Ciencias Biológicas, Universidad Nacional Autónoma de México". We would like to thank José F. González-Maya and Andrés Arias-Alzate for support, review and insightful comments about the manuscript. Finally, we are indebted to Ronald Bjorkland for his support in reviewing and editing the manuscript.

\section{Conflicts of interest}

The authors declare they have no conflict of interest.

\section{Author contributions}

Heliot Zarza: designed the research, conducted the experiments, analysed the data, and wrote the manuscript.

Gerardo Suzán: designed the research, analysed the data, and revised the manuscript. Enrique Martínez-Meyer: designed the research and analysed the data.

Gerardo Ceballos: designed the research, analysed the data, and edited the manuscript.

\section{References}

1. Acha P, Szyfres B. Zoonosis y enfermedades transmisibles comunes al hombre y a los animales: clamidiosis, rickettsiosis y virosis. $3^{\text {rd }}$ ed. Lima (PE): Organización Panemerica de la Salud; 2003.

2. Johnson N, Vos A, Freuling C, Tordo N, Fooks AR, Muller T. Human rabies due to lyssavirus infection of bat origin. Vet Microbiol. 2010;142(3-4):151-9. doi: 10.1016/j.vetmic.2010.02.001.

3. Velasco-Villa A, Orciari LA, Juarez-Islas V, Gomez-Sierra M, Padilla-Medina I, Flisser $A$, et al. Molecular diversity of rabies viruses associated with bats in Mexico and other countries of the Americas. J Clin Microbiol. 2006;44(5):1697-710. doi: 10.1128/JCM.44.5.1697-1710.2006.

4. Constantine DG. Bat rabies and other lyssavirus infections. Reston VA (US): U. S. Geological Survey; 2009.

5. Heymann DL. El control de las enfermedades transmisibles. 18th ed. Washington DC (USA): Organización Panemericana de la Salud; 2005.

6. World Health Organization. Rabia. Nota descriptiva Nº9; 2016. 
7. Belotto A, Leanes LF, Schneider MC, Tamayo H, Correa E. Overview of rabies in the Americas. Virus Res. 2005;111(1):5-12. doi: 10.1016/j.virusres.2005.03.006.

8. Lee DN, Papes M, Van den Bussche RA. Present and potential future distribution of common vampire bats in the Americas and the associated risk to cattle. PLoS One. 2012;7(8):e42466. doi: 10.1371/journal.pone.0042466.

9. Schneider MC, Romijn PC, Uieda W, Tamayo H, da Silva DF, Belotto A, et al. Rabies transmitted by vampire bats to humans. Rev Panam Salud Pública. 2009;25(3):260-9. doi: 10.1590/S1020-49892009000300010.

10. Organización Panamericana de la Salud / Organización Mundial de Salud. Vigilancia epidemiológica de la rabia en las Américas. Rio de Janeiro (BR)2004.

11. Anderson A, Shwiff S, Gebhardt K, Ramirez AJ, Shwiff S, Kohler D, et al. Economic evaluation of vampire bat (Desmodus rotundus) rabies prevention in Mexico. Transbound Emerg Dis. 2012;61(2):140-6. doi: 10.1111/tbed. 12007.

12. Bárcenas-Reyes I, Loza-Rubio E, Zendejas-Martínez H, Luna-Soria H, CantóAlarcón GJ, Milián-Suazo F. Comportamiento epidemiológico de la rabia paralítica bovina en la región central de México, 2001-2013. Rev Panam Salud Publica. 2015;38(5).

13. Servicio Nacional de Sanidad Inocuidad y Calidad Agroalimentaria. Campaña Nacional para la prevención y control de la rabia en bovinos y especies ganaderas. Mexico.2016 [Available from: https://www.gob.mx/senasica/ acciones-y-programas/campana-nacional-para-la-prevencion-y-control-de-la-rabia-en-bovinos-y-especies-ganaderas].

14. Greenhall AM, Joermann G, Schmidt U. Desmodus rotundus. Mammalian Species. 1983;202:1-6.

15. Barquez R, Pérez S, Miller B, Díaz M. Desmodus rotundus: IUCN: International Union for Conservation of Nature; 2012 [Available from: www.iucn.org].

16. Greenhall AM, Schmidt U. Natural history of vampire bats. Florida: CRC Press, Inc.; 1988.

17. Ávila-Flores R, Medellín RA. Ecological, taxonomic, and physiological correlates of cave use by mexican bats. J Mammal. 2004;85:675-87

18. Villa-R B. Los murciélagos de México. Mexico City (MX): Universidad Nacional Autónoma de México; 1966.

19. George DB, Webb CT, Farnsworth ML, O'Shea TJ, Bowen RA, Smith DL, et al. Host and viral ecology determine bat rabies seasonality and maintenance. Proc Natl Acad Sci U S A. 2011 ; 108(25):10208-13. doi: 10.1073/pnas. 1010875108.

20. Peterson AT, Soberón J, Pearson RG, Anderson RP, Martínez-Meyer E, Nakamura $M$, et al. Ecological niches and geographic distributions. Princeton, New Jersey (US): Princeton University Press; 2011.

21. Soberon J. Grinnellian and Eltonian niches and geographic distributions of species. Ecol Lett. 2007;10(12):1115-23. doi: 10.1111/j.1461-0248.2007.01107.x.

22. Guisan A, Tingley R, Baumgartner JB, Naujokaitis-Lewis I, Sutcliffe PR, Tulloch $\mathrm{Al}$, et al. Predicting species distributions for conservation decisions. Ecol Lett. 2013;16(12):1424-35. doi: 10.1111/ele. 12189.

23. Hutchinson GE. An introduction to population ecology. New Haven (US): Yale University Press; 1978. p. 271.

24. Grinnell J. The niche-relationships of the California Thrasher. The Auk. 1917;34:427-33.

25. Elton C. Animal Ecology. First ed. New York: Macmillan Company; 1927. p. 260. 
26. GBIF Occurrence Download [Internet]. 2017 [cited 19 May]. Available from: http://www.gbif.org/.

27. México: Informes semanales sobre enfermedades y plagas de reporte obligatorio inmediato. [Internet]. 2016 [cited 8 February 2015]. Available from: http://www.gob.mx/senasica/acciones-y-programas/ sistema-nacional-de-vigilancia-epidemiologica-sive.

28. Censo agropecuario 2007. VIII Censo agrícola, ganadero y forestal [Internet]. 2009. Available from: http://www.inegi.org.mx/est/contenidos/proyectos/ Agro/ca2007/Resultados_Agricola/default.aspx.

29. Hijmans RJ, Cameron SE, Parra JL, Jones PG, Jarvis A. Very high resolution interpolated climate surfaces for global land areas. Int J Climatol. 2005;25(15):196578. doi: 10.1002/joc. 1276.

30. Instituto Nacional de Estadística y Geografía. Modelo Digital de Elevación. Mexico (MX).2009 [Available from: http://www.inegi.org.mx/geo/contenidos/ datosrelieve/continental/].

31. Environmental Systems Research Institute. ArcGIS. 9.3 ed. California2009.

32. Pachauri RK, Meyer LA. Climate change 2014: Synthesis report. Contribution of working groups I, II and III to the fifth assessment report of the Intergovernmental Panel on Climate Change. Geneva $(\mathrm{CH})$ : Intergovernmental Panel on Climate Change; 2014.

33. Phillips SJ, Anderson RP, Schapire RE. Maximum entropy modeling of species geographic distributions. Ecol Modell. 2006;190(3-4):231-59. doi: 10.1016/j. ecolmodel.2005.03.026.

34. Phillips SJ, Dudík M. Modeling of species distributions with Maxent: new extensions and a comprehensive evaluation. Ecography. 2008;31:161-75. doi: 10.1111/j.2007.0906-7590.05203.x.

35. Elith J, Graham CH, Anderson RP, Dudík M, Ferrier S, Guisan A, et al. Novel methods improve prediction of species' distributions from occurrence data. Ecography. 2006;29:129-51.

36. Elith J, Phillips SJ, Hastie T, Dudík M, Chee YE, Yates CJ. A statistical explanation of MaxEnt for ecologists. Divers Distrib. 2011;17(1):43-57. doi: 10.1111/j.1472-4642.2010.00725.x.

37. Santika T. Assessing the effect of prevalence on the predictive performance of species distribution models using simulated data. Glob Ecol Biogeogr. 2011;20(1):181-92. doi: 10.1111/j.1466-8238.2010.00581.x.

38. Muscarella R, Galante PJ, Soley-Guardia M, Boria RA, Kass JM, Uriarte M, et al. ENMeval: An R package for conducting spatially independent evaluations and estimating optimal model complexity forMaxentecological niche models. Methods Ecol Evol. 2014;5(11):1198-205. doi: 10.1111/2041-210x.12261.

39. Lobo JM, Jiménez-Valverde A, Real R. AUC: a misleading measure of the performance of predictive distribution models. Glob Ecol Biogeogr. 2007;17:145-51.

40. Lobo JM, Tognelli MF. Exploring the effects of quantity and location of pseudo-absences and sampling biases on the performance of distribution models with limited point occurrence data. J Nat Conserv. 2011;19(1):1-7. doi: 10.1016/j.jnc.2010.03.002.

41. Marino J, Bennett M, Cossios D, Iriarte A, Lucherini M, Pliscoff P, et al. Bioclimatic constraints to Andean cat distribution: a modelling application for rare species. Divers Distrib. 2011;17(2):311-22. doi: 10.1111/j.1472-4642.2011.00744.x. 
42. Jiménez-Valverde A, Lobo JM. Threshold criteria for conversion of probability of species presence to either-or presence-absence. Acta Oecol. 2007;31 (3):3619. doi: 10.1016/j.actao.2007.02.001.

43. Barve N, Barve V, Jiménez-Valverde A, Lira-Noriega A, Maher SP, Peterson AT, et al. The crucial role of the accessible area in ecological niche modeling and species distribution modeling. Ecol Modell. $2011 ; 222(11): 1810-9$. doi: 10.1016/j. ecolmodel.2011.02.011.

44. de Andrade FA, Gomes MN, Uieda W, Begot AL, Ramos Ode S, Fernandes ME. Geographical analysis for detecting high-risk areas for bovine/human rabies transmitted by the common hematophagous bat in the amazon region, Brazil. PLoS One. 2016;1 17):e0157332. doi: 10.1371/journal.pone.0157332.

45. de Thoisy B, Bourhy H, Delaval M, Pontier D, Dacheux L, Darcissac E, et al. Bioecological drivers of rabies virus circulation in a neotropical bat community. PLoS Negl Trop Dis. 2016;10(1):e0004378. doi: 10.1371/journal.pntd.0004378.

46. Delpietro HA, Marchevsky N, Simonetti E. Relative population densities and predation of the common vampire bat (Desmodus rotundus) in natural and cattle-raising areas in north-east Argentina. Prev Vet Med. 1992;14:13-20.

47. Moya MI, Pacheco LF, Aguirre LF. Relación de los ataques de Desmodus rotundus con el manejo del ganado caprino y algunas características del hábitat en la prepuna de Bolivia. Mastozool Neotrop. 2015;22:73-84.

48. Gomes MN, Monteiro AM, Lewis N, Goncalves CA, Filho VS. Landscape risk factors for attacks of vampire bats on cattle in Sao Paulo, Brazil. Prev Vet Med. 2010;93(2-3):139-46. doi: 10.1016/j.prevetmed.2009.10.006. 